\title{
Konsep Manusia Ideal: Tinjauan Teologis dan Pendidikan Islam
}

\author{
Nurti Budiyanti ${ }^{* 1}$, Asep Abdul Aziz ${ }^{* 2}$, Andewi Suhartini ${ }^{* 3}$, Nurwadjah \\ Ahmad $^{* 4}$, Ari Prayoga ${ }^{* 5}$ \\ ${ }^{* 1}$ Universitas Pendidikan Indonesia \\ ${ }^{* 2}$ UIN Sunan Gunung Djati Bandung \\ ${ }^{*}$ UIN Sunan Gunung Djati Bandung \\ ${ }^{*}$ UIN Sunan Gunung Djati Bandung \\ ${ }^{* 5}$ PERSMAPI Indonesia \\ Email: nurtibudiyanti@upi.edu ${ }^{* 1}$, asepabdulaziz19993@gmail.com ${ }^{* 2,}$ \\ andewi.suhartini@uinsgd.ac.id ${ }^{* 3}$, nurwadjah.ahmad@gmail.com ${ }^{* 4,}$ \\ ariprayoga@madrasah.id ${ }^{5}$
}

\begin{abstract}
Education is the process of fostering and developing human potential optimally that covers all dimensions of life, including soul, mind, and heart that shape human personality. However, in reality, education currently still focuses on the vocational aspects and unfortunately disregards personality. As a result, the to-beachieved goals are also partial and not comprehensive. Ideally, the concept of education should be normative and integrative because there is a goal to achieve in accordance with the views of educational practitioners about the ideal qualifications of human beings as expected which certainly involves the spirit of the Quran in all aspects of life. Therefore, this study provides an overview of the involvement of all aspects of life in shaping an ideal human concept established from the terms Bani Adam, Basyar, Insan, An-Naas, and 'Abdun. The present study employed a qualitative approach in the form of literature study as a means of collecting data. Based on the study results and analyses, it was found that the ideal human concept established from the terms Bani Adam, Insan, An-Naas, Basyar and 'Abdun is a mention for humans viewed from various aspects, such as historical, psychological, sociological, biological, and theological aspects. In fact, these five aspects indeed indicate the perfection of humans as God's creatures. In particular, the ideal human being is a person who is aware of his status as a servant of Allah, aware of his role and function as khalifatullah, and also aware of his life's purpose to always makrifatullāh. The educational implications of this concept cover goals, roles, functions, principles, educators, students,
\end{abstract}


teaching contents, methods, and educational media. All of those implications must have a positive impact on the mind and heart as a means of increasing all the potentials possessed by humans. Thus, all the components of education are used as a means of strengthening faith, straightening worship, and instilling noble character and conduct towards makrifatullah.

Keywords: Humans; ideal; theological; the islamic education.

\begin{abstract}
Abstrak
Pendidikan merupakan proses pembinaan dan pengembangan potensi manusia secara optimal yang menyentuh seluruh dimensi kehidupan, baik menyangkut jiwa, akal, dan hati yang membentuk kepribadian manusia. Namun realitanya, pendidikan saat ini masih menitikberatkan pada aspek vokasional, sedangkan kepribadian terabaikan, sehingga tujuan yang dicapaipun bersifat parsial, tidak keseluruhan. Seharusnya konsep pendidikan bersifat normatif dan integratif, karena ada arah yang ingin dituju sesuai dengan pandangan para praktisi pendidikan tentang kualifikasi ideal manusia yang diharapkan, yang tentunya melibatkan ruh Al-Quran di dalam seluruh aspek kehidupan. Penelitian ini memberikan gambaran mengenai keterlibatan seluruh aspek kehidupan dalam membentuk sebuah konsep manusia ideal yang dibangun dari term Bani Adam, Basyar, Insan, An-Naas, dan 'Abdun. Pendekatan dalam penelitian ini adalah pendekatan kualitatif, dengan teknik studi pustaka dalam pengumpulkan data. Berdasarkan hasil temuan dan analisis dalam penelitian ini didapatkan bahwa konsep manusia ideal yang dibangun dari term Bani Adam, Insan, An-Naas, Basyar dan 'Abdun merupakan penyebutan untuk manusia yang dilihat dari berbagai aspek, baik secara aspek historis, aspek psikologis, aspek sosiologis,aspek biologis maupun aspek teologis, yang mana kelima aspek itu menggambarkan kesempurnaan manusia sebagai makhluk Allah. Adapun secara khusus, manusia ideal merupakan manusia yang menyadari statusnya sebagai hamba Allah, menyadari peran dan fungsinya sebagai khalifatullah, juga menyadari tujuan hidunya untuk senantiasa makrifatulläh. Adapun implikasi edukatif dari konsep ini meliputi tujuan, peran, fungsi, prinsip, pendidik, peserta didik, materi, metode dan media pendidikan. Kesemuanya itu harus memberikan pengaruh positif pada akal dan hati dalam meningkatakan seluruh potensi yang dimiliki oleh manusia. Dengan demikian, seluruh kompenen pendidikan tersebut diarahkan untuk mengokohkan akidah, meluruskan ibadah, dan mensholehkan akblakul karimah menuju makrifatullāh.
\end{abstract}


Kata Kunci: Manusia; ideal; teologis; pendidikan islam.

\section{Pendahuluan}

Al-Quran telah mencakup seluruh konsep kehidupan, di dalamnya terdapat kandungan yang secara garis besar dapat dibagi menjadi beberapa hal pokok, yakni akidah, ibadah, akhlak, hukum, sejarah, serta ilmu pengetahuan. Hal tersebut menjadikan alasan mengapa Al-Quran merupakan pedoman hidup manusia, yang harus senantiasa diketahui oleh seluruh umat manusia. Di antara kandungan Al-Quran yang sangat penting adalah mengenai konsep manusia. Melihat tinjauan Al-Quran, begitu banyak Allah menyinggung pembahasan mengenai konsep manusia dengan penyebutan yang berbeda-beda. Allah menjelaskan dengan penyebutan Bani Adam, Basyar, Insan, An-Naas, dan 'Abdun. Sudah jelas nampaknya Allah menjabarkan mengenai segala sesuatu di muka bumi ini, termasuk mengenai proses penciptaan manusia dalam konsep manusia tersebut. Bagaimana seorang manusia dapat tercipta di dunia ini sebagai makhluk yang paling mulia di bumi ${ }^{1}$.

Mengenai konsep ini, orientalis berbeda pandangan dengan konsep Al-Qur'an bahkan mengklaim sebagai kitab yang tidak sistematis. Melihat perbedaan itu, orientalis tersebut menuduh bahwa Al-Quran tidak konsisten atau bahkan mereka menuduh Al-Quran sebagai kitab yang kacau, dengan alasan banyaknya pesan yang diulang di banyak kesempatan. Dalam proses penciptaannya pun mereka menganggap bahwa manusia diciptakan dari tanah yang diulang-ulang di enam kesempatan, dari tanah liat tujuh kesempatan, dari tembikar di empat kesempatan, dan dari sari pati air yang hina, air yang tertumpah, dan mani yang dipancarkan masing-masing satu kali. Sehingga dibutuhkan pengkajian lebih mendalam untuk menyingkap permasalahan tersebut ${ }^{2}$.

Deskripsi di atas memicu umat Islam untuk lebiha memepelajari dan mendalami kandungan makna dan maksud-maksud tersirat dalam Al-Qur'an sekaligus membuktikan bahwa Al-Qur'an merupakan kitab yang sangat sistematis baik diksi, pengulangan

${ }^{1}$ Afrida Afrida, 'Hakikat Manusia Dalam Perspektif Al-Qur'an', Al-Qisthu: Jurnal Kajian Ilmu-Ilmu Hukum, 16.02 (2018), 54-59.

2 Himmatul Istiqomah, “Konsep Manusia Sebagai Insan Dalam Sebagian Ayat Al-Qur'an," Prosiding Konfererensi Nasional Bahasa Arab 04, no. 04 (2018): 439-45. 
maupun kesesuaian konteks kejadiannya. Membuktikan bahwa AlQuran merupakan referensi yang lengkap tentang konsep manusia termasuk pembinaan dan pendidikannya, baik intelektualitas, prilaku, moral, maupun spiritual. Al-Quran memberikan bimbingan secara komprehensif dan integratif, di dalamnya terdapat sebuah konsep yang bertujuan untuk memberikan solusi dari berbagai permasalahan yang ada. Dalam Al-Quran penyebutan kata Bani Adam diulang sebanyak 7 kali, kata Basyar diulang sebanyak 36 kali, kata Insan diulang sebanyak 65 kali, kata An-Naas diulang sebanyak 240 kali, sementara kata 'Abdun diulang sebanyak 140 kali. Keempat term tersebut memiliki kecenderungan yang sama dalam penyebutan kata manusia. Adapun perbedaanya terlihat pada konteks ayat yang menentukan tempat kata itu berada. Walau demikian, redaksi kata tersebut saling berkaitan. Keempat term inilah yang kemudian akan membentuk konsep manusia ideal perspektif Al-Quran yang tentunya menunjang dalam merumuskan implikasi edukatif teori pendidikan Islam ${ }^{3}$.

\section{Metode Penelitian}

Studi ini bertujuan untuk memperoleh gambaran mengenai konsep manusia ideal dalam perspektif Al-Quran, yang dibangun dari integrasi term Bani Adam, Insan, An-Naas, Basyar dan 'Abdun. Studi ini dilakukan untuk menyelidiki dan menggali ayat Al-Quran berdasarkan tinjauan beberapa ahli tafsīr dalam kitab $\mathrm{Mu}^{\prime}$ tabaroh $^{4}$. Desain penelitian ini menggunakan pendekatan kualitatif ${ }^{5}$, dengan metode non interaktif (analisis dokumen) ${ }^{6}$. Peneliti menghimpun, mengidentifikasi, menganalisis, dan mengadakan sintesis data, untuk kemudian memberikan interpretasi terhadap konsep manusia ideal dalam persepktif Al-Quran. Yang digunakan peneliti adalah metode

${ }^{3}$ Masrohan Masrohan, “Hakikat Manusia Dalam Al-Quran," Wahana Akademika: Jurnal Studi Islam Dan Sosial 01, no. 01 (May 2016): 29-40.

4 Ari Prayoga and Dewi Qorotul Kaffah, 'Manajemen Sarana Dan Prasana Perspektif Al Quran Dan Hadis', TARBIYA ISLAMIA : Jurnal Pendidikan Dan Keislaman, 08.02 (2019), 165-79.

${ }^{5}$ Irawan Irawan, Filsafat Manajemen Pendidikan Islam, ed. by Koko Khoerudin, 1st edn (Bandung: PT. Remaja Rosdakarya, 2019).

6 Sugiyono, Metode Penelitian Pendidikan Pendekatan Kuantitatif, Kualitatif, Dan $R \mathcal{}$, 7th ed. (Bandung: Alfabeta, 2009). 
maudhu'i, yaitu mengumpulkan ayat-ayat al-qur'an yang mempunyai tujuan yang satu yang bersama-sama membahas judul/topik/sektor tertentu dan menertibkannya sedapat mungkin sesuai dengan masa turunnya selaras dengan sebab-sebab turunnya, kemudian memperhatikan ayat-ayat tersebut dengan penjelasan-penjelasan, keterangan-keterangan dan hubungan-hubungannya dengan ayatayat lain, kemudian mengistinbatkan hukum-hukum7.

\section{Hasil Penelitian dan Pembahasan}

Keterkaitan Term Bani Adam, Insan, An-Naas, Basyar dan 'Abdun dalam Membentuk Sebuah Konsep Manusia Ideal dalam Perspektif Al-Quran

Manusia telah berupaya memahami dirinya selama beribu-ribu tahun. Tetapi gambaran yang pasti dan meyakinkan tak mampu mereka peroleh hanya dengan mengandalkan daya nalarnya yang subjektif. Oleh karena itu mereka memerlukan pengetahuan dari pihak lain yang dapat memandang dirinya secara lebih utuh. Allah Sang Pencipta telah menurunkan Kitab Suci Al-Quran, yang di dalamnya berkaitan dengan konsep manusia. Penyebutan nama manusia dalam Al-Qur'an lebih dari satu kali seperti dijelaskan dalam bukunya Azyumardi Azra korelasinya dengan aspek kehidupan manusia. Berikut disajikan salah satu ayat yang mewakali masingmasing term penyebutan manusia di antaranya ialah ${ }^{8}$ :

\begin{tabular}{|c|c|}
\hline & 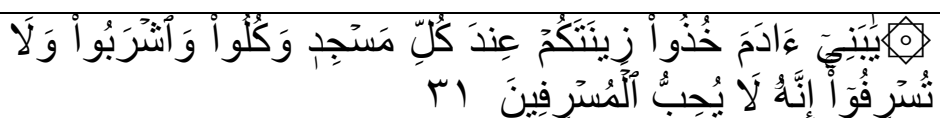 \\
\hline Historis & \\
\hline $\begin{array}{l}\text { Penciptaan } \\
\text { Manusia }\end{array}$ & $\begin{array}{l}\text { "Hai anak Adam, pakailah pakaianmu } \\
\text { yang indah di setiap (memasuki) }\end{array}$ \\
\hline & $\begin{array}{l}\text { mesjid, makan dan minumlah, dan } \\
\text { janganlah } \\
\text { berlebih-lebihan. }\end{array}$ \\
\hline Bani Adam & Sesungguhnya Allah tidak menyukai \\
\hline
\end{tabular}

7 Zainul Hamdi, Menilai Ulang Gagasan Integrasi Ilmu Pengetahuan Sebagai Blue Print Pengembangan Keilmuan UIN, ed. Zainal Abidin Bagir (Yogyakarta: MYIA-CRCS \& Suka Press, 2005), 183-185.

8 Azyumadi Azra, Pendidikan Agama Islam Pada Perguruan Tinggi Umum (Jakarta: DEPAG, 2002), 13. 


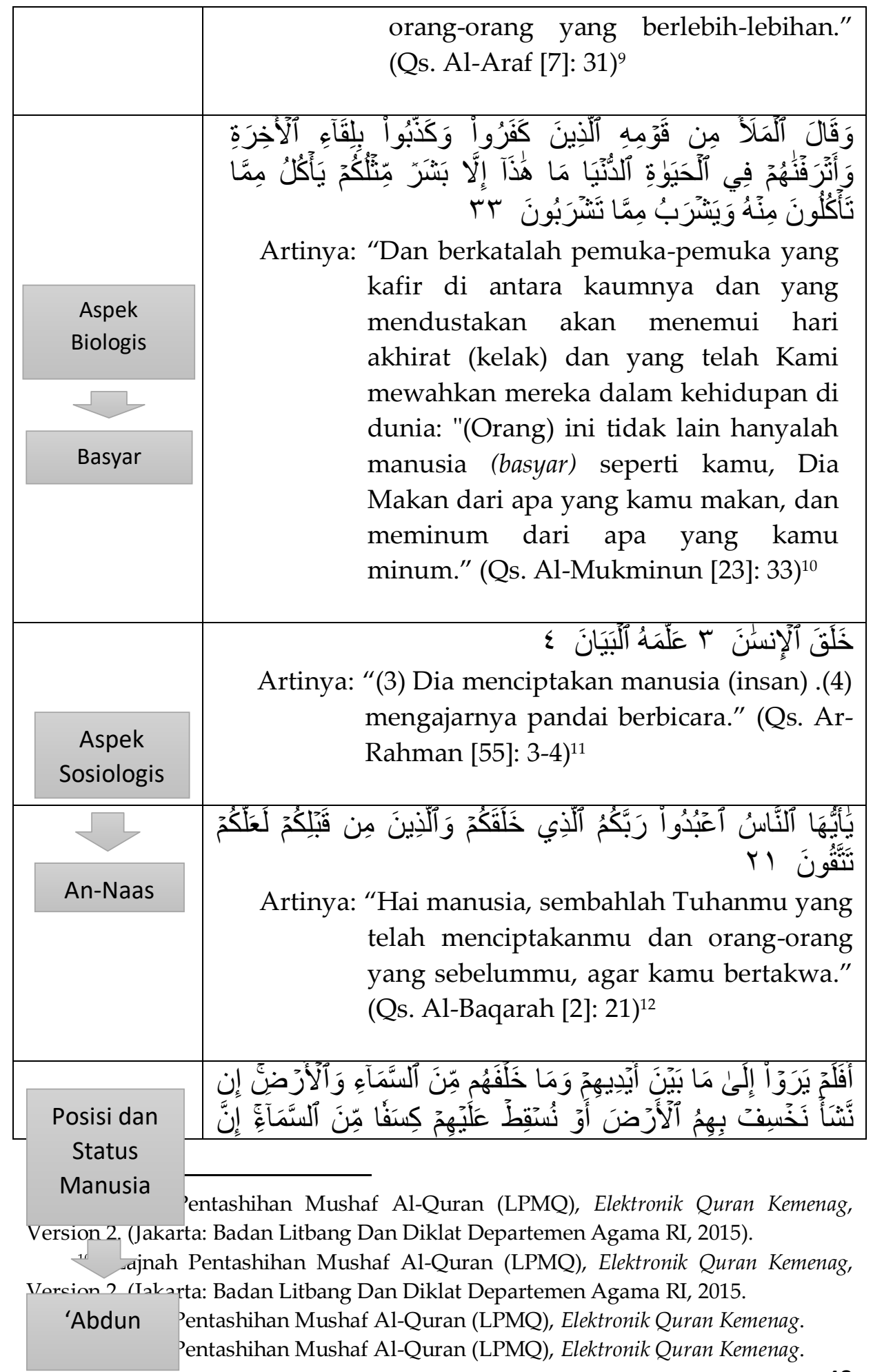




\begin{tabular}{|c|c|c|}
\hline & Artinya: & 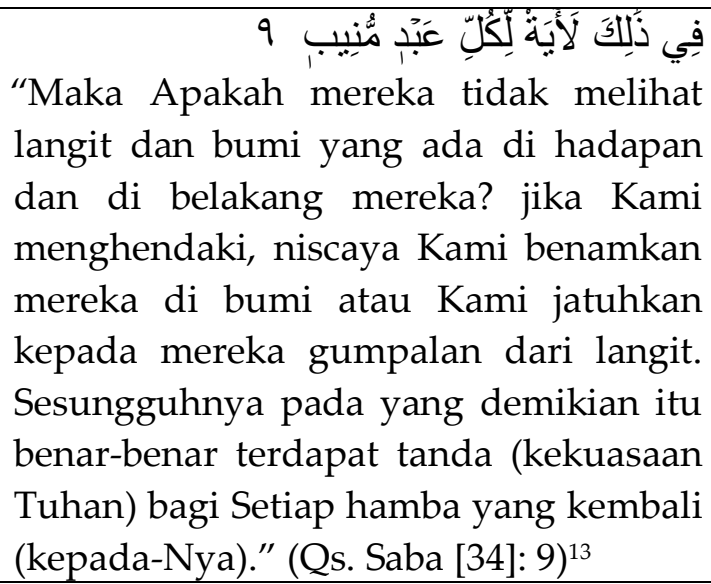 \\
\hline
\end{tabular}

Bani Adam yang terdapat dalam Qs. Al-Araf ayat 31 di atas, AlQurthubi menafsirkan bahwa term ini memiliki ungkapan yang ditujukan kepada seluruh alam, meski maksudnya adalah bangsa Arab yang berada di sekitar Ka'bah. Adapun menurut Hamka seruan "Hai anak Adam" adalah untuk disampaikan kepada seluruh anak Adam. Bahwa Agama Islam ini bukanlah khusus untuk suatu bangsa saja, melainkan benarlah Muhammad Saw., itu rahmat bagi seluruh alam, baik laki-laki maupun perempuan. Sementara itu, Husein menegaskan bahwa pada ayat ini Adam merupakan nenek moyang umat manusia, yang karenanya Adam adalah manusia pertama. Kesimpulan ini sejalan dengan hadis yang menyatakan bahwa manusia seluruhnya berasal dari Adam dan Adam diciptakan dari tanah atau debu. Oleh karenya tinjauan historis penciptaan manusia dikenal dengan sebutan Bani Adam.

Basyar yang terdapat dalam Qs. Al-Mukminun ayat 33 artinya manusia yang berasal dari kata Basyarah ( $\mathrm{mufrad} / \mathrm{kata}$ tunggal) yang artinya kulit luar. Pemaknaan kata Al-Basyar di beberapa kata dalam Al-Quran seluruhnya memberikan pengertian bahwa yang di maksud dengan kata tersebut adalah dzurriyati adam. Sehingga kata basyar terambil dari akar kata yang pada mulanya berarti penampakan sesuatu dengan baik dan indah. Dari akar kata yang sama, lahir kata basyarah yang berarti kulit. Manusia dinamai basyar karena kulitnya tampak jelas, dan berbeda dengan kulit binatang yang lain. Pengertian dari kata Al-Basyar nampak pada bentuk fisiknya (lahiriyah), yang secara

${ }_{13}$ Lajnah Pentashihan Mushaf Al-Quran (LPMQ), Elektronik Quran Kemenag. 
umum satu dengan yang lainnya memiliki persamaan. Berkaitan dengan hal ini, maka dalam aspek biologis manusia dikenal dengan sebutan Basyar.

Insan yang terdapat dalam Qs. Ar-Rahman ayat 3-4 mencakup semua jenis manusia, sejak Adam as., hingga akhir zaman. Kata insan ialah bentuk mufrad untuk tunggal, sama dengan kata insan bentuk jamaknya anaas seperti dalam Al-Quran surat an-Naas dalam surat alBaqarah ayat 60, serta anasiyun dalam Al-Quran surat al-Furqan ayat 49. Kata insan digolongkan kepada jenis laki-laki/mudzakar, dan kadang digolongkan kepada jenis perempuan/muannas menunjukan arti taifah/kelompok masyarakat. Adapun menurut ibn Mandzur kata insan dalam lisan al 'arab dapat diambil dari tiga akar kata yaitu annasa, an-nisa, dan nasia. Kata insan ini digunakan dalam Al-Quran untuk menunjuk kepada manusia dengan seluruh totalitasnya, jiwa dan raga. Manusia yang berbeda antara seorang dengan yang lain, akibat perbedaan fisik, mental dan kecerdasan. Kata al-insān dituturkan sampai 65 kali dalam Al-Quran dan dikelompokkan ke dalam tiga kategori: (a) al-insān dihubungkan dengan khalīfaћ sebagai penunggang amanah (Qs. Al-Aḥzab ayat 72), (b) al-insān yang dihubungkan dengan predisposisi negatif dalam diri manusia misalnya sifat keluh kesah, kikir (Qs. Al-Ma'ārij ayat 19-21), (c) al-insān dihubungkan dengan proses penciptaan yang terdiri dari unsur materi dan nonmateri (Qs. Al-Hijr ayat 28-29). Semua konteks al-insān ini merujuk pada sifat-sifat manusia psikologis dan spiritual. Berdasarkan penjelasan tersebut maka dalam aspek psikologis manusia dikenal dengan sebuatan Al-Insan ${ }^{14}$.

An-Naas yang terdapat dalam Qs. Al-Baqarah ayat 21 merupakan seruan yang ditujukan kepada seluruh warga Mekah ${ }^{15}$. Kemudian, ditambahkan oleh ar-Rifa'i bahwa warga Mekah di sini adalah kepada mereka orang-orang kafir dan orang-orang munafik untuk menyembah dan meng-esa-kan Allah Swt ${ }^{16}$. Sedangkan kata annaas disebut sebanyak 240 kali dalam Al-Quran mengacu kepada manusia sebagai makhluk sosial dengan karakteristik tertentu

${ }^{14}$ D. K. Yusuf and D. Rasyidin, Syariah Leadership (Bandung: Tafakur, 2008), 3.

15 I. J. Al-Mahalli and I. J. As-Suyuti, Tafsir Jalalain (Bandung: Sinar Baru Algensindo, 2007), 11.

${ }_{16}$ M. N. Ar-Rifa'i, Kemudahan Dari Allah Ringkasan Tafsir Ibnu Katsir (Jakarta: Gema Insani, 1999), 91. 
misalnya mereka mengaku beriman padahal sebenarnya tidak (Qs. AlBaqarah ayat 8). An-Naas menunjukkan pada eksistensi manusia sebagai makhluk sosial secara keseluruhan Allah telah menciptakan manusia dalam bentuk struktur yang sempurna. Berdasarkan penjelasan inilah dari aspek sosiologis manusia dikenal dengan sebutan $\mathrm{An}$-Naas ${ }^{17}$.

'Abdun yang terdapat dalam Qs. Saba ayat 9 diambil dari kata muniib yang memiliki maksud sebagai mana yang dijelaskan oleh Abdullah ${ }^{18}$ dalam Tafsir Ibnu Katsir jilid 7, bahwa al-muniib memiliki arti "yang kembali" yaitu yang bertaubat. Sufyan dari Qatadah berkata: "Al-Muniib adalah orang yang menghadapkan dirinya kepada Allah." Yaitu, sesungguhnya dalam mengamati penciptaan langit dan bumi mengandung petunjuk bagi setiap hamba yang pandai, cerdik, dan yang kembali kepada Allah atas kekuasaan-Nya dalam membangkitkan jasad-jasad dan terjadinya hari kembali. Kata muniib terambil dari kata an-nawb yang pada mulanya berarti turun, kemudian maknanya berkembang sehingga dipahami juga dalam arti kembali, yakni kembali ke posisi semula setelah ditinggalkan. Ini mengandung makna intropeksi dan menyesali perbuatan lalu memperbaiki diri. Karena itu, kata ini juga dipahami dalam arti bertobat dan kembali kepada Allah. Berdasarkan penjelasan inilah dalam aspek teologis manusia dikenal dengan sebutan 'Abdun.

Keempat term tersebut menggambarkan keistimewaan manusia dalam Al-Quran. Untuk menguraikan status manusia sebagai 'Abdun, divisualisasikan ke dalam bentuk bagan berikut ini:

17 M. Arifin, Ilmu Pendidikan Islam Tinjauan Teoretis Dan Praktis Berdasarkan Pendekatan Interdisipliner (Jakarta: Bumi Aksara, 2008), 42.

18 Abdullah, Tafsir Ibnu Katsir (Jakarta: Pustaka Imam Asy-Syafi'i, 2008), 357. 


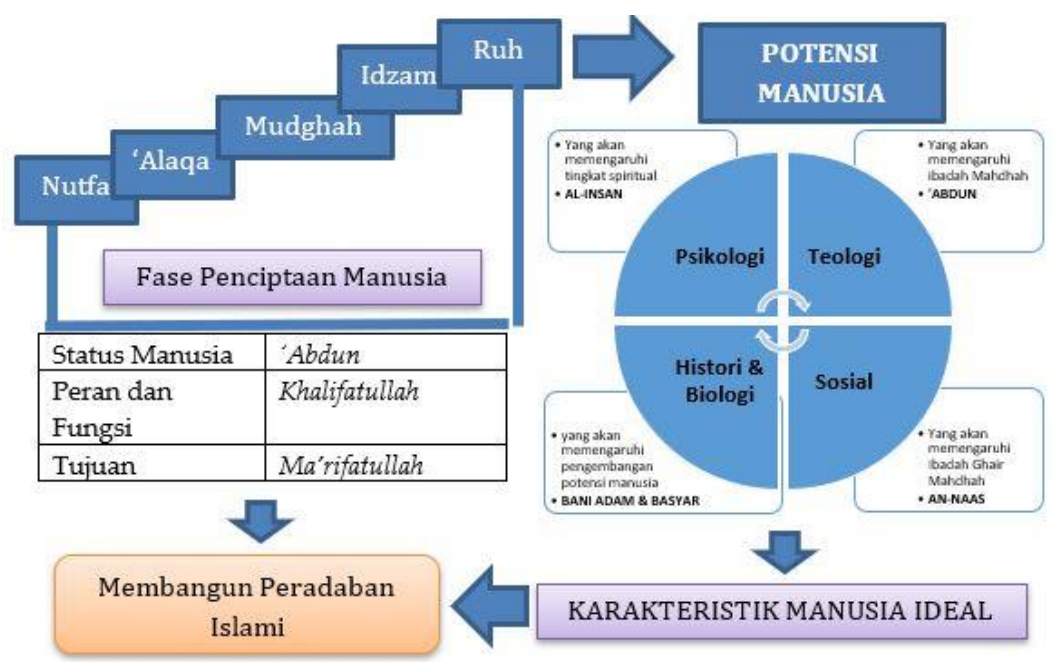

Bagan 1. Hubungan Term Bani Adam, Insan, An-Naas, Basyar dan 'Abdun

Berdasarkan bagan di atas, terlihat bahwa fase penciptaan manusia mengantarkan seorang untuk mengungkap potensi yang ada dalam dirinya. Mengenai penciptaan manusia ini, Husein dalam dewi mengungkapkan sekurang-kurangnya ada 34 ayat di dalam Al-Quran yang menjelaskannya dan ke 34 ayat itu tersebar dalam 16 surat. Secara singkatnya 34 ayat tersebut dapat dikemukakan 4 macam keterangan dengan mengambil sampel 4 surat yakni Qs. Al-Qiyamah ayat 37-39, Qs. Al-Mu'minun ayat 12-14, Qs. Sajadah ayat 7-9, dan Qs. Al-Hajj ayat 5. Manusia diciptakan melalui beberapa tahapan yakni : (1) penciptaan manusia pertama kali dari tanah atau sari pati tanah (2) dari setetes mani yang ditumpahkan ke dalam rahim, (3) menjadi embrio ('alaqoh), (4) menjadi segumpal daging (mudghoh), (5) terbentuk tulang dan kemudian dibungkus daging, (6) menyempurnakan dan meniupkan roh kepadanya dan menjadikan kepadanya kemampuan pendengaran, penglihatan dan hati, (7) tercipta makhluk yang baru, (8) menjadikannya berpasang-pasangan terdiri dari laki-laki dan perempuan. Begitulah Allah menciptakan manusia melalui beberapa tahapan, sehingga Allah menjadikan manusia dalam bentuk yang sebaik-baiknya. Manusia menurut Suhrawardi merupakan hasil dari proses evolusi penciptaan alam semesta. Manusia adalah makhluk dua dimensi, di satu pihak terbuat dari tanah yang menjadikannya 
makhluk fisik, di pihak lain manusia juga makhluk spiritual karena ditiupkan ke dalam dirinya roh yang berasal dari Tuhan ${ }^{19}$.

Berdasarkan bagan hubungan term Bani Adam, Insan, An-Naas, Basyar dan 'Abdun di atas, terlihat sangat tegas bahwa status manusia ialah sebagai 'abdun yang memiliki tugas luhur yakni beribadah kepada Allah sebagaimana termaktub dalam Qs. Al-Dzariyat ayat 56. Semua penciptaan, termasuk manusia bertujuan untuk mengenal kesempurnaan Tuhan. Tujuan penciptaan manusia diuraikan ke dalam beberapa visi. Sebagaimana Mufid mengungkapkan bahwa peran dan fungsi manusia ialah sebagai khalifatullah sebagaimana termaktub dalam Qs. Al-Baqarah ayat 31 yang dibekali dengan visi Ilāhiyyah dan kawniyah yang kemudian dikembangkan kepada istilah Ilāhiyyah, insāniyyah (ilmiah), dan kawniyyah (alamiah) untuk memperdekat kepada orientasi pembahasan manusia dan ekosistemnya dalam konteks paradigma baru ekologi manusia ${ }^{20}$.

Khalifah adalah makhluk yang melaksanakan tugas-tugas kehidupan di muka bumi secara optimal sesuai dengan kapasitasnya, dalam koridor ketentuan atau aturan yang telah ditetapkan Allah, baik dalam motivasi, bentuk tindakan maupun efek yang ditimbulkan. Manusia diberikan kebebasan dalam membuat dan melaksanakan kebijaksanaan, serta diberi pedoman yang berfungsi sebagai kendali dalam membuat kebijaksanaannya. Dalam memaknai khalifah fil ardh, manusia memegang amanah untuk pengembangan kebudayaan dan peradaban yang benar, yang selaras dengan normanorma Tuhan yang memerlukan kemampuan-kemampuan kerja, kemampuan nalar yang benar, kemampuan apresiatif, memiliki kemauan dan kehendak, serta kekuatan spiritual21.

Sejalan dengan kelebihan dan keistimewaan manusia, tujuan pokok diciptakannya ialah merealisasikan peran dan fungsi manusia sebagai khalifah untuk ma'rifatullah. Tujuan ini ditempatkan sebagai tujuan esensial yang membedakan antara manusia dengan makhluk lainnya seperti malaikat dan jin. Manusia bisa menjadi hamba Allah,

19 Ernita Dewi, 'Konsep Manusia Ideal Dalam Persepektif Suhrawardi AlMaqtul', Jurnal Substantia, 17.01 (2015), 41-54.

${ }^{20}$ Happy Susanto, “Filsafat Manusia Ibnu Arab," Jurnal Tsaqafah 10, no. 01 (2014): 109-126.

${ }^{21}$ Ahmad Syamsu Rizal, 'Filsafat Pendidikan Islam', Jurnal Pendidikan Agama Islam - Ta'lim, 12.01 (2014), 1-18. 
ketika ia memenuhi fungsinya sebagai khalïfah. Itu artinya, tugas utama manusia ialah beribadah dan mentauhidkan-Nya, sehingga hatinya penuh dengan ma'rifatullah.

\section{Telaah Teologis Terkait Karakteristik Manusia Ideal dalam Perspektif Al-Quran}

Pandangan Islam terhadap manusia lebih komprehensif yang mana telah diciptakan Allah sebagai makhluk yang sempurna dan mulia, manusia diberi akal pikiran sebagai khalīfah di muka bumi sebagai wakil Allah, untuk mengelola bumi dan isinya, serta membuat peradaban. Apa pun yang ada pada tubuh manusia sudah dirakit dalam suatu tatanan yang terbaik dan sempurna. Pemberian bentuk tubuh beserta fungsinya. Sebagaimana Allah menegaskan bahwa ${ }^{22}$ :

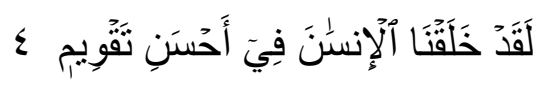

Menurut Quthb dalam tafsir Jalalain menjelaskan bahwa ayat ini menunjukkan bagaimana perhatian Allah dalam menciptakan manusia di dalam bentuk yang sebaik-baiknya, tetapi di khususkannya penyebutannya di sini dan di tempat-tempat lain dalam Al-Quran dengan susunan yang sebaik-baiknya, bentuk yang sebaik-baiknya, dan keseimbangan yang sebaik-baiknnya. Sedangkan menurut tafsir Al-Aitsar kata Fii ahsani taqwiim ialah dalam bentuk yang paling bagus, seimbang dan dengan postur tubuhnya yang sangat indah ${ }^{23}$. Senada dengan itu, Ibnu Katsir mengatakan bahwa Allah telah menciptakan manusia dalam bentuk yang sebaik-baiknya, dengan perawakan yang sempurna serta beranggotakan badan yang normal. Adapun kata Taqwim bisa diartikan sebagai acuan, simetris, bentuk, kodrat, sosok tubuh. Tak ada yang salah dalam ciptaan Allah. Allah memberikan sifat yang terbaik dan paling murni kepada manusia, dan kewajiban manusia adalah menjaga pola yang telah dibuat Allah untuk manusia. Dengan pola itulah manusia berhak

22 Sutarman Sutarman, Haryono Edihermawan, and Agus Salim, 'Hidupan Manusia Dengan Membudayakan Pendidikan Dan Sistem NIlai-Nilai Islami', Rausyan Fikr Jurnal Pemikiran Dan Pencerahan, 13.02 (2017), 1-12.

${ }^{23}$ A. B. Al-Jaziri, Tafsir Al-Qur'an Al-Aisar (Vol. 7) (Jakarta Timur: Darus Sunnah Press, 2009), 969. 
dikatakan sebagai manusia ideal, karena Allah telah memperhatikan segala aspek yang terbaik untuk manusia ${ }^{24}$.

Konsepsi Islam tentang manusia ideal yang sering mendapat doktrin menjadi al-Insān al-Kämil (the universal or perfect man). Al-Insān al-Kāmil ini esensi dan manifestasi utuhnya dapat dijumpai pada Nabi Muhammad, sementara teoritisasinya secara baik telah diterangkan oleh Ibn Arabi dan Jalal al-Din Rumi ${ }^{25}$. Ibn Arabi dalam penelitiannya menyajikan konsep tentang manusia sempurna (al-Insān al-Kāmil), yaitu manusia yang mampu mengaktualisasikan semua potensialitasnya sesuai dengan bentuk Tuhan secara lengkap ${ }^{26}$. Dalam diri manusia sempurna sangat berbeda dengan makhluk hewan karena manusia mampu mewujudkan setiap kualitas yang terpuji. Mereka ini menjadi teladan bagi kebijaksanaan, kasih sayang dan segala kebaikan moral serta spiritual manusia. Manusia sempurna membimbing individu dan masyarakat sampai titik tertinggi menuju Tuhan, bertindak mencerminkan tindakan Tuhan di dalam masyarakat, mengarahkan orang pada kebahagiaan tertinggi di alam akhirat. Juga sebagai penyambung risalah $\mathrm{Nabi}^{27}$.

Konsep mengenai manusia ideal dan paripurna (al-Insān alKāmil) dalam Islam merupakan kajian yang cukup menarik dan amat penting untuk diketahui. Al-Insān al-Kāmil adalah sebuah keserasian dua bentuk dalam diri manusia. Bentuk yang pertama adalah ada kesempurnaan dari segi wujud yang meliputi semua perangkat perangkat yang ada dalam diri manusia. Kesempurnaan semacam ini adalah anugerah dari Allah Swt. dan juga merupakan hasil dari manifestasi atas kemampuan menjaga diri dari segala bentuk yang dapat melukai dan membahayakan diri serta kesanggupan untuk memanfaatkannya. Sedangkan yang kedua adalah kesempurnaan pengetahuan. Kesempurnaan pengetahuan ini didadasari oleh keingintahuan untuk memperoleh pengetahuan. Rasa ingin tahu itupun mengharuskan manusia untuk mampu memanfaatkan atau

${ }^{24}$ A. Y. Ali, The Holy Qur'an, Text, Translation and Commentary, ed. A. Audah (Jakarta: Pustaka Firdaus, 1985), 16-28.

${ }^{25}$ K. M Yusuf, 'Indera Manusia Menurut Alquran Dan Psikologi Konvensional', Jurnal Hadhari, 06.02 (2013), 55-69.

${ }^{26}$ Saleha Idris, 'Insan Kamil : Theological and Psychological Perspectives', Asian Journal of Social Sciences, Arts and Humanities, 05.02 (2017), 9-28.

27 Susanto, “Filsafat Manusia Ibnu Arab", 109 
menggunakan potensi yang ada dalam dirinya untuk meraih ilmu pengetahuan sebanyak-banyaknya. Namun tidak hanya cukup sekadar memperoleh, tapi hendaknya ilmu yang dimiliki manusia digunakan sejalan dengan tuntunan syariat yang dibawa oleh utusan$\mathrm{Nya}^{28}$.

Al-Insān al-Kāmil merupakan manusia ideal dengan derajat tertinggi dibandingkan makhluk lain. Perannya sebagai khalifah Allah Swt sebagai pemimpin dunia, menjadikan dunia tetap aman dan damai. Al-Insān al-Kāmil bukan hanya seseorang yang sempurna akan fisiknya, tetapi seseorang yang sempurna akan pengetahuannya. Seperti konsep al-Insān al-Kāmil yang dikembangkan oleh Suhrawardi. Pengetahuan seorang al-Insān al-Kāmil berbeda dengan pengetahuan orang biasa, karena al-Insān al-Kāmil memperoleh pengetahuan dari sumber pengetahuan itu sendiri. Menurut Suhrawardi seseorang yang telah menggabungkan daya intelektual (rasional) dan daya intuisi, sehingga orang tersebut memperoleh pengetahuan maka orang tersebut dapat dikatakan sebagai al-Insān al-Kāmil. Dalam pandangannya pula, al-Insān al-Kāmil adalah seorang filsuf tidak hanya seseorang yang memiliki pengetahuan rasional saja, tetapi sekaligus menjadi orang suci, orang yang tercerahkan dalam pengetahuan Ilāhi ${ }^{29}$.

Sementara itu, konsep manusia sempurna seperti yang ditulis Soejono Redjo dalam subhi menunjukkan pada penjelasan tentang manusia sempurna yaitu manusia yang lupa akan diri, tenggelam dalam kekhusyuan beribadah ${ }^{30}$. Sebagaimana para ahli lain menyebutnya sebagai manusia unggul. Seseorang yang berpribadian unggul akan tergambar jelas keimanannya melalui amal perbuatan dalam kehidupan sehariannya ${ }^{31}$. Dengan kembali ke keadaan primordial (fitrah), dan ke realitas diri sebagai hamba Allah yang setia, sadar akan dirinya sebagai wakil Allah (khalifah), mewujudkan

${ }^{28}$ Harahap, Musaddad, and Lina Mayasari Siregar, 'Konsep Pendidikan Islam Dalam Membentuk Manusia Paripurna', Jurnal Pendidikan Agama Islam Al-Thariqah, 02.02 (2017), 148-59.

${ }^{29}$ Dewi, “Konsep Manusia Ideal Dalam Persepektif Suhrawardi Al-Maqtul", 51.

30 Siti Saudah and Nusyirwan, 'Konsep Manusia Sempurna', Jurnal Filsafat, 14.02 (2007), 185-191.

${ }^{31}$ Nurrahman, 'Konsep Manusia Unggul: Kajian Atas Naskah Anis Al-Muttaqin', Jurnal Lektur Keagamaan, 11.01 (2015), 181-202. 
kefanaan, dan akhirnya, melalui peniadaan ego, bersama akal dalam diri, mencapai Zat Tertinggi, Sang Realitas ${ }^{32}$.

Manusia, pada hakikatnya, mempunyai kecenderungan yang inheren pada dirinya untuk mencapai sesuatu yang secara moral diyakininya baik. Dengan ungkapan lain dikatakan bahwa manusia senantiasa berada dalam perjalanan eskatalogis menuju keutamaan moralitas. Moralitas, selanjutnya, dijadikan ukuran kesempurnaan manusia. Karena itu, moralitas adalah masalah paling sentral dalam semua agama. Dalam ajaran Islam untuk menumbuhkan nilai nilai moralitas dikenal sebagai nilai nilai spiritual. Untuk dapat menghadirkan nilai-nilai spiritual, perlu menumbuhkan kesadaran ilāhiyyah untuk mendekatkan diri kepada Allah ${ }^{33}$.

Untuk meningkatkan nilai spiritual, ada langkah dan upaya yang harus dilakukan seseorang, yakni tazkiyatu al-nafs, mujāhadah, dan riyadhah. Bagi seseorang yang akan menjalani kehidupan tasawuf harus menempuh maqam-maqam (tahapan spritual), yakni taubat, zuhud, faqir, sabar, tawakal dan ikhlas. Bagi seseorang yang menjalani tasawuf, setelah menempuh maqam (kedudukan atau tahapan spiritual), maka akan merasakan kondisi spiritual yakni muraqabah, qurbah, muhabbah, khauf, raja', syauq, uns dan musyahadah ${ }^{34}$. Untuk mencapai demikian, diperlukan beberapa proses yang harus dilalui terlebih dulu, yakni proses takhalī (pengosongan hati dari sifat tercela), tahalī (pengisian hati dari sifat terpuji), dan tajalì (pendekatan diri kepada Allah). Tahapan inilah yang akan mengantarkan manusia menjadi manusia ideal yang diharapkan Allah, divisualisasikan ke dalam bagan berikut ${ }^{35}$ :

${ }^{32}$ Mohamamad Subhi, 'Doktrin Manusia Universal Dalam Antropologi Metafisis Seyyed Hossein Nasr', Jurnal Universitas Paramadina, 11.03 (2014), 28-45.

33 Sodiman, 'Menghadirkan Nilai-Nilai Spritual Tasawuf Dalam Proses Mendidik', Jurnal Al-Ta'dib, 06.01 (2014), 33-44.

34 Fahrudin, 'Tasawuf Sebagai Upaya Bembersihkan Hati Guna Mencapai Kedekatan Dengan Allah', Jurnal Pendidikan Agama Islam Ta'lim, 01.01 (2016), 65-83.

35 Wahyudi Setiawan, 'The Spiritual Education Toward Insan Kamil in the Education of Modern Humankind', in International Seminar Education Muhammadiyah University of Ponorogo (Ponorogo: Muhammadiyah University of Ponorogo, 2016), 1-7. 


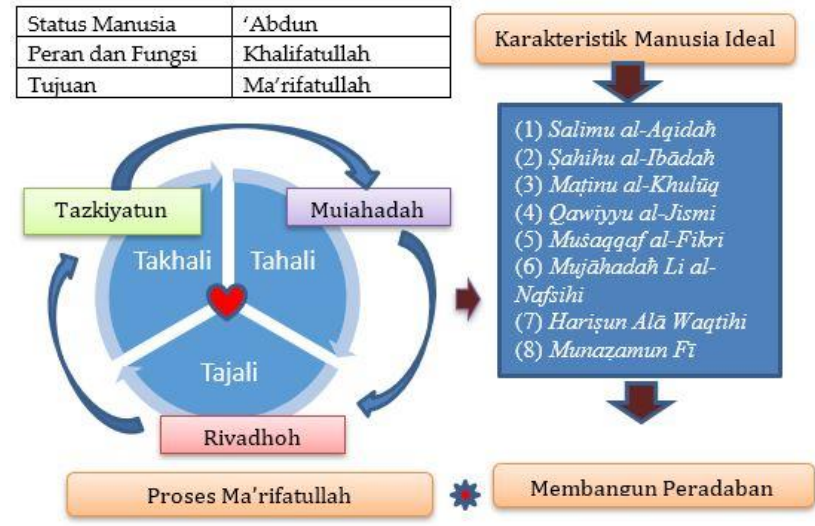

Bagan 2. Karakteristik Manusia Ideal

Berdasarkan bagan di atas, proses ma'rifatullah dapat mengantarkan seorang hamba dalam membangun peradaban Islami, karena memiliki karakteristik yang sempurna baik dalam segi aqidah, ibadah, akhlak maupun spiritualnya. Sebagaimana 10 karakteristik tersebut dijabarkan oleh Hasan Al-Bana dalam merumuskan 10 karakteristik muslim yang dibentuk di dalam madrasah tarbawi. Karakteristik ini seharusnya yang menjadi ciri khas dalam diri seseorang yang mengaku sebagai muslim, di antaranya ialah: (1) Salimu al-Aqidah: dengan aqidah yang bersih, seorang muslim akan memiliki ikatan yang kuat kepada Allah Swt dan dengan ikatan yang kuat itu dia tidak akan menyimpang dari jalan dan ketentuanketentuan-Nya. (2) Sahihu al-Ibādah: ibadah yang benar merupakan salah satu perintah Rasulullah Saw yang penting dan tidak boleh ada unsur penambahan atau pengurangan. (3) Maținu al-Khulūq: akhlak yang mulia merupakan sikap dan prilaku yang harus dimiliki oleh setiap muslim, baik dalam hubungannya kepada Allah maupun dengan makhluk-makhluk-Nya ${ }^{36}$.

Dengan akhlak yang mulia, manusia akan bahagia dalam hidupnya, baik di dunia maupun di akhirat. (4) Qawiyyu al-Jismi: kekuatan jasmani berarti seorang muslim memiliki daya tahan tubuh sehingga dapat melaksanakan ajaran Islam secara optimal dengan fisiknya yang kuat. (5) Musiaqqaf al-Fikri: intelek dalam berfikir merupakan salah satu sisi pribadi muslim yang penting. Karena itu

${ }^{36}$ Rusdiana Navlia Khulaisie, 'Hakikat Kepribadian Muslim , Seri Pemahaman Jiwa Terhadap Konsep Insan Kamil', Jurnal Refletika, 11.11 (2016), 39-57. 
salah satu sifat Rasul adalah fațonah (cerdas) dan Alquran banyak mengungkap ayat-ayat yang merangsang manusia untuk berpikir. (6) Mujāhadah Li al-Nafsihi : berjuang melawan hawa nafsu merupakan salah satu kepribadian yang harus ada pada diri seorang muslim, karena setiap manusia memiliki kecenderungan pada yang baik dan yang buruk. (7) Harișun Alā Waqtihi: pandai menjaga waktu merupakan faktor penting bagi manusia. Hal ini karena waktu itu sendiri mendapat perhatian yang begitu besar dari Allah dan RasulNya. (8) Munaẓamun Fì Syūnihi: teratur dalam suatu urusan termasuk kepribadian seorang muslim yang harus ditekankan, baik yang terkait dengan masalah ubudiyah maupun muamalah harus diselesaikan dan dilaksanakan dengan baik. (9) Qadīrun Alā al-Kasbi: memiliki kemampuan usaha sendiri atau yang juga disebut dengan mandiri merupakan ciri lain yang harus ada pada seorang muslim untuk mempertahankan dan menegakkan kebenaran. (10) Nafi'un Li Ghairihi: manfaat yang dimaksud tentu saja manfaat yang baik sehingga di mana pun dia berada, orang disekitarnya merasakan keberadaannya karena bermanfaat besar ${ }^{37}$.

Dengan demikian konsep ini mampu mengantarkan menuju makrifatullah. Makrifatullah merupakan sumber dan puncak kelezatan beribadah yang dilakukan oleh seorang manusia di dunia ini. Mengenal dan mencintai Sang Pencipta dengan sepenuhnya. Dengan demikian manusia akan memperoleh yang luar biasa dari yang lainnya. Ma'rifat kepada Allah adalah sifat yang sangat mulia ${ }^{38}$. Dengan hati terus bermakrifat, nilai-nilai Islam semakin melekat. Islam sangat menjunjung tinggi nilai-nilai humanisme dan memelihara kemaslahatan hidup manusia, menjaga dan memelihara akal, jiwa, harta, keturunan, dan harga diri, termasuk amar $m a^{\prime} r u \bar{f}$ dan nahī munkar yang menjadi spirit pola kehidupan

37 Rusdiana Navlia Khulaisie, 'Hakikat Kepribadian Muslim , Seri Pemahaman Jiwa Terhadap Konsep Insan Kamil', Jurnal Refletika, 11.11 (2016), 39-57.

38 Murni, 'Konsep Ma'rifatullah Menurut Al-Ghazali (Suatu Kajian Tentang Implementasi Nilai-Nilai Akhlak Al-Karimah)', International Journal of Islamic Studies, 02.01 (2014), 123-146. 
kaum muslimin ${ }^{39}$. Sehingga manusia dijadikan sebagai cermin yang dapat mendeteksi Ilāhi ${ }^{40}$.

\section{Implikasi Konsep Manusia Ideal terhadap Teori Pendidikan Islam}

Al-Quran sebagai petunjuk dengan berbagai tema di dalamnya memberikan berbagai solusi disetiap permasalahan yang dihadapi setiap orang yang membacanya. Begitupun halnya dengan pendidikan, Al-Quran baik secara tersirat maupun tersurat memberikan gambaran sebagai solusi tentang bagaimana pendidikan seharusnya dilakukan. Pada hakikatnya Al-Quran merupakan sumbernya tarbiyyah, Allah sebagai murabbi, manusia sebagai mutarabbi. Bila dikaji secara mendalam, setiap ayat dalam Al-Quran berisikan nilai-nilai pendidikan. Konsep manusia ideal yang dibicarakan dalam Al-Quran ini memiliki sentral implikasi terhadap beberapa komponen pendidikan Islam, divisualisasikan ke dalam bentuk bagan berikut:

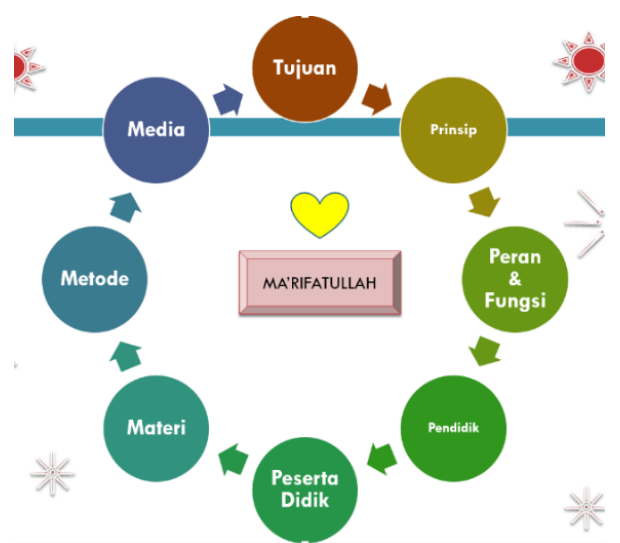

Bagan 3. Implikasi Edukatif Konsep Manusia Ideal

Setelah melewati kajian tentang konsep manusia ideal maka pengertian pendidikan Islam adalah sebuah upaya penyadaran status manusia sebagai hamba Allah dan perannya sebagai khalifatullah, serta proses menumbuhkembangkan, menguatkan dan mengaktualisasikan seluruh potensi yang dimiliki dalam kehidupan

39 Sukarman, 'Urgensi Pendidikan Holistik Dalam Membentuk Insan Kamil', Jurnal Tarbawi, 02.02 (2014), 2088-3102.

40 Cinar Kaya, 'Rumi from the Viewpoint of Spiritual Psychology and Counseling', Journal Spiritual Psychology and Counseling, 01.01 (2016), 5-21. 
sehari hari agar dapat menjadi manusia yang beriman, bertaqwa dan berakhlakul karimah. Hal ini selaras dengan apa yang termaktub dalam Undang-Undang Nomor 20 tahun 2003 tentang Sistem Pendidikan Nasional dinyatakan bahwa: Pendidikan adalah usaha sadar dan terencana untuk mewujudkan suasana belajar dan proses pembelajaran agar peserta didik secara aktif mengembangkan potensi dirinya untuk memiliki kekuatan spiritual keagamaan, kepribadian, kecerdasan, akhlak mulia, serta keterampilan yang diperlukan dirinya, masyarakat Bangsa dan Negara.

Berdasarkan deskripsi di atas, tujuan pendidikan Islam adalah menyempurnaan iman, taqwa, dan akhlak, serta aktif membangun peradaban dan keharmonisan kehidupan, khususnya dalam memajukan peradaban bangsa yang bermartabat dengan ma'rifatullah. Hal ini selaras dengan apa yang disampaikan oleh para pakar pendidikan yang menuturkan bahwa pendidikan Islam merupakan suatu upaya untuk mencapai kualitas ketakwaan kepada Allah SWT ${ }^{41}$. Dengan terbinanya sikap religius baik pada pola pikir, sikap hidup, serta memanfaatkan kemampuan untuk kehidupan manusia dengan motif untuk memperoleh ridho Allah dalam menggapai ma'rifatullāh ${ }^{42}$.

Peran dan Fungsi Pendidikan Islam ialah sebagai fasilitator dalam membina jiwa, akal dan hati. Sehingga, tolak ukur yang utama ialah meningkatkan kecerdasan intelektual, spriritual dan emosional. Sebagaimana Muhaimin menegaskan bahwa peran dan fungsi pendidikan ialah (1) Mengembangkan pengetahuan teoritis, praktis dan fungsional bagi peserta didik. (2) Menumbuhkan kreativitas, potensi-potensi atau fitrah peserta didik. (3) Meningkatkan kualitas akhlak dan kepribadian, atau menumbuhkembangkan nilai-nilai insani dan nilai Ilāhi. (4) Menyiapkan tenaga kerja yang produktif;. (5) Membangun peradaban yag berkualitas (sesuai dengan nilai-nilai Islam) di masa depan. (6) Mewariskan nilai-nilai Ilāhi dan nilai-nilai insāni peserta didik.

Prinsip Pendidikan Islam, melalui pengkajian konsep manusia ideal ini yang dibangun dari term Bani Adam, Insan, An-Naas, Basyar

41 Yedi Purwanto, 'Ajaran Al-Qur'an Dalam Membentuk Karakter', Jurnal Pendidikan Agama Islam, 13.01 (2015), 17-36.

42 Ahmad Syamsu Rizal, 'Perumusan Tujuan Sebagai Basis Pengembangan Kurikulum Pendidikan Islam', Jurnal Pendidikan Agama Islam-Ta'lim, 12.02 (2014), 97112. 
dan 'Abdun yang terdapat dalam Qs. Al-'Araf ayat 31, Qs. AlMukminun ayat 33, Qs. Ar-Rahman ayat 3-4, Qs. Al-Baqarah ayat 21, Qs. Saba ayat 9 \& Qs. At-Tiin ayat 4 mengenai manusia ideal maka tersirat beberapa prinsip yakni prinsip Rabbaniyyah (Ketuhanan), prinsip Rahmaniyyah (kasih sayang), prinsip wasaliyyah (kemediaan), dan prinsip tawazuniyyah (keseimbangan). Hal ini selaras dengan apa yang dikemukakan oleh pakar tafsir yakni terdapat enam prinsip pendidikan dalam Al-Quran, yakni prinsip Raḥmāniyyah (Kasih Sayang), prinsip Takāmuliyyah (integratif), prinsip Wașāliyyah (Kemediaan), prinsip Syumūliyyah (komprehensif, universal), prinsip Tawāzuniyyah (keseimbangan), dan prinsip Rabbāniyyah (Ketuhanan) ${ }^{43}$.

Pendidik dalam Pendidikan Islam, melalui pengkajian konsep manusia ideal ini pendidik merupakan seorang manusia yang sempurna yang berkewajiban untuk menumbuhkembangkan peserta didik baik dari segi kecerdasan intelektual, kecerdasan sosial dan kecerdasan spiritual. Peran dang fungsi seorang pendidik dijabarkan sebagai berikut: (1) Seorang pendidik harus mampu menanamkan ketauhidan yang kuat terhadap anak didiknya. (2) Seorang pendidik harus mampu mengarahkan aktifitas spiritual yang baik dan benar. (3) Seorang pendidik harus mampu membina pribadi anak didik menuju tabiat yang lurus, baik itu membina jiwa, akal maupun hati. (4) Seorang pendidik harus mampu memiliki keterampilan untuk membina kesadaran anak didiknya, agar lebih dekat kepada Rabb yang menciptakannya.

Peserta didik dalam Pendidikan Islam, melalui pengkajian konsep manusia ideal ini peserta didik merupakan seseorang yang sedang berjuang untuk menumbuhkembangkan potensinya dengan baik. Dari konsep ini peserta didik diharuskan memiliki kriteria tertentu yakni: 1) Peserta didik harus memberdayakan akal dan hatinya untuk senantiasa berfikir, memahami, serta merenungi berbagai informasi yang tersampaikan. (2) Peserta didik harus memiliki kesadaran yang tinggi dalam membina aqidah yang kuat, ibadah yang sehat serta tabi'at yang lurus. (3) Peserta didik harus tunduk dan patuh terhadap perintah serta nasehat yang diberikan oleh pendidik.

43 A. Abdussalam, "Pembelajaran Dalam Alquran Al-Karim Bandung" (UIN Sunan Kalijaga, 2011), 162-163. 
Materi Pendidikan Islam, melalui pengkajian konsep manusia ideal ini materi yang sudah selayaknya diperdalam oleh para peserta didik ialah materi yang berkaitan dengan agama, yang dimana disana terdapat kesatuan materi antara ilmu, iman, amal dan akhlak. Sehingga materi tersebut jika dikembangkan mengandung nilai-nilai Ilāhiyyah untuk senantiasa berma'rifatullah. Sebagaimana hal ini dituturkan oleh Arifin, bahwa materi-materi yang diuraikan dalam Alquran menjadi bahan-bahan pokok pelajaran yang disajikan dalam proses pendidikan Islam, formal, maupun nonformal. Oleh karena itu, materi pendidikan Islam yang bersumber dalam Alquran harus dipahami, dihayati, diyakini dan diamalkan dalam kehidupan umat Islam ${ }^{44}$.

Metode Pendidikan Islam, melalui pengkajian konsep manusia ideal ini yang dibangun dari term Bani Adam, Insan, An-Naas, Basyar dan 'Abdun yang terdapat dalam Qs. Al-'Araf ayat 31, Qs. AlMukminun ayat 33, Qs. Ar-Rahman ayat 3-4, Qs. Al-Baqarah ayat 21, Qs. Saba ayat 9 \& Qs. At-Tiin ayat 4 mengenai manusia ideal maka tersirat adanya metode 'ibrah maw'izah. Hal ini selaras dengan apa yang disampaikan oleh Syahidin metode yang berasal dari Al-Quran ialah (1) Metode Amś̄̄l, yakni metode perumpamaan. (2) Metode kisah Qurāni, yakni metode yang diambil dari kisah-kisah atau peristiwa yang terjadi pada umat terdahulu (3) Metode 'Ibrah Maw'izah, yakni metode berupa pengambilan pelajaran dan pemberian nasehat. (4) Metode Targib-Tarhib, yakni metode yang menggunakan strategi bujukan dan ancaman. (5) Metode Uswāḥ Hasanah, yakni metode pemberian teladan yang baik. (6) Metode Hiiwār Qurāni, yakni metode yang memberlakukan sistem dialog, mengadakan suatu percakapan atau pembicaraan yang silih berganti antara dua pihak atau lebih yang dilakukan melalui tanya jawab ${ }^{45}$.

Media Pendidikan Islam, melalui pengkajian konsep manusia ideal ini manusia memiliki potensi yang diberikan oleh Allah yang dapat dijadikan sebagai media pembelajaran sebagaimana ditegaskan dalam Qs. An-Nahl ayat 78 bahwa Al-Quran memberikan jawaban

44 Arifin, Ilmu Pendidikan Islam Tinjauan Teoretis Dan Praktis Berdasarkan Pendekatan Interdisipliner, 135.

45 D. H. Syahidin, Menelusuri Metode Pendidikan Dalam Alquran (Bandung: Alfabeta, 2009), 79-163. 
mengenai empat sarana untuk meraih ilmu, yaitu pendengaran, penglihatan, akal dan hati. Empat sarana tersebut merupakan media Islami yang mutlak diberikan Allah untuk digunakan sebaik mungkin agar memperoleh kebenaran yang objektif. Begitu pun dalam penelitian ini mengindikasikan adanya media pembelajaran, dengan memanfaatkan alat indra, alam semesta serta makhluk ciptaan Allah ${ }^{46}$.

\section{Kesimpulan}

Konsep manusia ideal yang dibangun dari term Bani Adam, Insan, An-Naas, Basyar dan 'Abdun merupakan penyebutan untuk manusia yang dilihat dari berbagai aspek, baik secara aspek historis, aspek psikologis, aspek sosiologis, aspek biologis maupun aspek teologis, yang mana kelima aspek itu menggambarkan kesempurnaan manusia sebagai makhluk Allah. Adapun secara khusus, manusia ideal merupakan manusia yang menyadari statusnya sebagai hamba Allah, menyadari peran dan fungsinya sebagai khalifatullah, juga menyadari tujuan hidunya untuk senantiasa makrifatullāh. Adapun implikasi edukatif dari konsep ini meliputi tujuan, peran, fungsi, prinsip, pendidik, peserta didik, materi, metode dan media pendidikan. Kesemuanya itu harus memberikan pengaruh positif pada akal dan hati dalam meningkatakan seluruh potensi yang dimiliki oleh manusia. Dengan demikian, seluruh kompenen pendidikan tersebut diarahkan untuk mengokohkan akidah, meluruskan ibadah, dan mensholehkan akhlakul karimah menuju makrifatullāh.

\section{Daftar Pustaka}

Abdullah, Tafsir Ibnu Katsir (Jakarta: Pustaka Imam Asy-Syafi'i, 2008) Abdussalam, A., 'Pembelajaran Dalam Alquran Al-Karim Bandung' (UIN Sunan Kalijaga, 2011)

Afrida, Afrida, 'Hakikat Manusia Dalam Perspektif Al-Qur'an', AlQisthu: Jurnal Kajian Ilmu-Ilmu Hukum, 16.02 (2018), 54-59 $<$ https://doi.org/10.32694/010510>

Al-Jaziri, A. B., Tafsir Al-Qur'an Al-Aisar (Vol. 7) (Jakarta Timur: Darus Sunnah Press, 2009)

46 Ari Prayoga and Mohammad Sulhan, 'Pesantren Sebagai Penangkal Radikalisme Dan Terorisme', 5.2 (2019), 163-77. 
Al-Mahalli, I. J., and I. J. As-Suyuti, Tafsir Jalalain (Bandung: Sinar Baru Algensindo, 2007)

Ali, A. Y., The Holy Qur'an, Text, Translation and Commentary, ed. by A. Audah (Jakarta: Pustaka Firdaus, 1985)

Ar-Rifa'i, M. N., Kemudahan Dari Allah Ringkasan Tafsir Ibnu Katsir (Jakarta: Gema Insani, 1999)

Arifin, M., Ilmu Pendidikan Islam Tinjauan Teoretis Dan Praktis Berdasarkan Pendekatan Interdisipliner (Jakarta: Bumi Aksara, 2008)

Azra, Azyumadi, Pendidikan Agama Islam Pada Perguruan Tinggi Umum (Jakarta: DEPAG, 2002)

Dewi, Ernita, 'Konsep Manusia Ideal Dalam Persepektif Suhrawardi Al-Maqtul', Jurnal Substantia, 17.01 (2015), 41-54

Fahrudin, 'Tasawuf Sebagai Upaya Bembersihkan Hati Guna Mencapai Kedekatan Dengan Allah', Jurnal Pendidikan Agama Islam Ta'lim, 01.01 (2016), 65-83

Hamdi, Zainul, Menilai Ulang Gagasan Integrasi Ilmu Pengetahuan Sebagai Blue Print Pengembangan Keilmuan UIN, ed. by Zainal Abidin Bagir (Yogyakarta: MYIA-CRCS \& Suka Press, 2005)

Harahap, Musaddad, and Lina Mayasari Siregar, 'Konsep Pendidikan Islam Dalam Membentuk Manusia Paripurna', Jurnal Pendidikan Agama Islam Al-Thariqah, 02.02 (2017), 148-59 <https://doi.org/ doi:10.25299/althariqah.2017.vol2(2).1040>

Idris, Saleha, 'Insan Kamil: Theological and Psychological Perspectives', Asian Journal of Social Sciences, Arts and Humanities, 05.02 (2017), 9-28

Irawan, Irawan, Filsafat Manajemen Pendidikan Islam, ed. by Koko Khoerudin, 1st edn (Bandung: PT. Remaja Rosdakarya, 2019)

Istiqomah, Himmatul, 'Konsep Manusia Sebagai Insan Dalam Sebagian Ayat Al-Qur'an', Prosiding Konfererensi Nasional Bahasa Arab, 04.04 (2018), 439-45 <http://prosiding.arab-um.com/index. php/konasbara/article/view/307>

Kaya, Cinar, 'Rumi from the Viewpoint of Spiritual Psychology and Counseling', Journal Spiritual Psychology and Counseling, 01.01 (2016), 5-21 <https://doi.org/doi:10.12738/spc.2016.1.0001>

Khulaisie, Rusdiana Navlia, 'Hakikat Kepribadian Muslim , Seri Pemahaman Jiwa Terhadap Konsep Insan Kamil', Jurnal Refletika, 11.11 (2016), 39-57 <http://jurnal.umk.ac.id/index.php/ 
RE/article/download/447/478>

Lajnah Pentashihan Mushaf Al-Quran (LPMQ), Elektronik Quran Kemenag, Version 2. (Jakarta: Badan Litbang Dan Diklat Departemen Agama RI, 2015)

Masrohan, Masrohan, 'Hakikat Manusia Dalam Al-Quran', Wahana Akademika: Jurnal Studi Islam Dan Sosial, 01.01 (2016), 29-40 <https://doi.org/10.21580/wa.v1i1.799>

Murni, 'Konsep Ma'rifatullah Menurut Al-Ghazali (Suatu Kajian Tentang Implementasi Nilai-Nilai Akhlak Al-Karimah)', International Journal of Islamic Studies, 02.01 (2014), 123-146

Nurrahman, 'Konsep Manusia Unggul: Kajian Atas Naskah Anis AlMuttaqin', Jurnal Lektur Keagamaan, 11.01 (2015), 181-202

Prayoga, Ari, and Dewi Qorotul Kaffah, 'Manajemen Sarana Dan

Prasana Perspektif Al Quran Dan Hadis', TARBIYA ISLAMIA:

Jurnal Pendidikan Dan Keislaman, 08.02 (2019), 165-79 <https://doi.org/10.36815/tarbiya.v8i2.479>

Prayoga, Ari, and Mohammad Sulhan, 'Pesantren Sebagai Penangkal Radikalisme Dan Terorisme', 5.2 (2019), 163-77

Purwanto, Yedi, 'Ajaran Al-Qur'an Dalam Membentuk Karakter', Jurnal Pendidikan Agama Islam, 13.01 (2015), 17-36

Rizal, Ahmad Syamsu, 'Filsafat Pendidikan Islam', Jurnal Pendidikan Agama Islam - Ta'lim, 12.01 (2014), 1-18

- - - 'Perumusan Tujuan Sebagai Basis Pengembangan Kurikulum Pendidikan Islam', Jurnal Pendidikan Agama Islam-Ta'lim, 12.02 (2014), 97-112

Saudah, Siti, and Nusyirwan, 'Konsep Manusia Sempurna', Jurnal Filsafat, 14.02 (2007), 185-191 <https://doi.org/doi:10.22146/jf.31 332>

Setiawan, Wahyudi, 'The Spiritual Education Toward Insan Kamil in the Education of Modern Humankind', in International Seminar Education Muhammadiyah University of Ponorogo (Ponorogo: Muhammadiyah University of Ponorogo, 2016), pp. 1-7

Sodiman, 'Menghadirkan Nilai-Nilai Spritual Tasawuf Dalam Proses Mendidik', Jurnal Al-Ta'dib, 06.01 (2014), 33-44

Subhi, Mohamamad, 'Doktrin Manusia Universal Dalam Antropologi Metafisis Seyyed Hossein Nasr', Jurnal Universitas Paramadina, 11.03 (2014), 28-45

Sugiyono, Metode Penelitian Pendidikan Pendekatan Kuantitatif, Kualitatif, 
Dan RED, 7th edn (Bandung: Alfabeta, 2009) $<$ http://opac.depok.go.id:8123/inlislite3/opac/detailopac?id=15711>

Sukarman, ‘Urgensi Pendidikan Holistik Dalam Membentuk Insan Kamil', Jurnal Tarbawi, 02.02 (2014), 2088-3102

Susanto, Happy, 'Filsafat Manusia Ibnu Arab', Jurnal Tsaqafah, 10.01 (2014), 109-26 <https://doi.org/doi:10.21111/tsaqafah.v10i1.66>

Sutarman, Sutarman, Haryono Edihermawan, and Agus Salim, 'Hidupan Manusia Dengan Membudayakan Pendidikan Dan Sistem NIlai-Nilai Islami', Rausyan Fikr Jurnal Pemikiran Dan Pencerahan, 13.02 (2017), 1-12

Syahidin, D. H., Menelusuri Metode Pendidikan Dalam Alquran (Bandung: Alfabeta, 2009)

Yusuf, D. K., and D. Rasyidin, Syariah Leadership (Bandung: Tafakur, 2008)

Yusuf, K. M, 'Indera Manusia Menurut Alquran Dan Psikologi Konvensional', Jurnal Hadhari, 06.02 (2013), 55-69 